\title{
Arabic Calligraphy and the "Herbal" of al-Ghâfiqî: A Survey of Arabic Manuscripts at McGill University
}

\section{by Adam Gacek}

Rare book collections in the McGill University Libraries bouse a significant number of Oriental books, in addition to Western European works. Among them there are over 650 Islamic manuscripts. This is a brief survey of those manuscripts written in Arabic, irrespective of their provenance. The present article includes a list of signed calligraphs and a description of the "Herbal" of al-Ghafiqi, two outstanding features of the Arabic collections.

En plus des ouvrages venant de l'Europe de l'Ouest, les collections de livres anciens des bibliotbèques de l'université McGill comptent un nombre assez important de recueils orientaux. Parmi ceux-ci figurent plus de 650 manuscrits islamiques. Cet article donne un bref aperçu des manuscrits rédigés en arabe, quelle que soit leur provenance. La liste des calligrapbies signées et une description de l'Herbier" d'al-Ghâfiqi, deux fleurons des collections arabes, en font d'ailleurs partie.

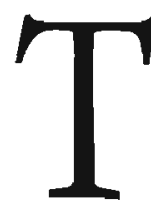

he McGill University Libraries house four collections of Islamic manuscripts. The languages represented are Arabic, Persian, Ottoman Turkish and Urdu. These collections are located in McLennan Library, Islamic Studics Library, Osler Library and Blacker-Wood Library. Until now these manuscripts have received very little attention from scholars of Islamic studies. A large number of them have remained in obscurity since the 1920 s due to insufficient cataloguing data. All together there are over 650 handwritten codices, 280 of which are in Arabic or Arabic and Persian. 'The Arabic manuscripts form a collection of approximatcly 290 individual compositions covering almost all of the traditional Islamic disciplines such as Qur'anic Studies, Tradition, Jurisprudence, Philosophy, Theology, Philology, Natural History, Medicine, Mathematics and Astronomy. In addition to the manuscripts, the Department of Rare Books and Special Collections in McLennan Library possesses a valuable collection of over 200 Arabic calligraphs and fragments (usually single leaves), some 82 of which are signed.

\section{THE COLLECTIONS}

\section{Osler Collection}

The Osler collection, which consists mainly of Arabic and Persian manuscripts, was obtained from Sir William Osler (1849-1919), a famous McGill professor, and from the ophthalmologist and ornithologist, Dr. Casey A. Wood (1856-1942), a McGill graduate. The manuscripts donated by Sir William Osler were acquired mainly from a great admirer of his, a certain Dr. M. Sa'eed of Hamadan (Iran). From the point of view of provenance, the manuscripts donated by Dr. Wood fall into two groups. The first group constitutes manuscripts originally collected during the period 1926-1927 by the Russian scholar Wladimir Ivanow (1886-1970), then cataloguer of Persian manuscripts at the Royal Asiatic Society of Bengal and formerly Curator of Pcrsian manuscripts in the Imperial Library at St. Petersburgh. The second group is made up of the manuscripts accuired from the German physician and Arabist Dr. Max Meyerhof (1874-1945), who spent some thirty years practising medicine in Egypt.' 
The Arabic manuscripts in the Osler collection number some 58 individual works (79) with copies thereof) and, with the exception of one codex, all are broadly within the field of medicine. There are two dated manuscripts going back to the 7 th/13th century and one from the $8 \mathrm{th} / 14 \mathrm{th}$ century. The most famous is the illustrated "Herbal" of al-Ghâfiçî (ms 7508) described below. The collection also counts among its other rare itcms a copy of alMu âlajàt al-buqrâtîyab (ms 225) of Abû alHasan Ahmad al-Tabari (fl. 4th/10th century) dated Shawwal $611 / 1215$ and a copy of the commentary by Nasîn al-Dîn al-Tûsî (d. 672/1274) on Ibn Sìnâ's al-Ishàràt wa-altanbibât ( $\mathrm{ms} 478$ ). This manuscript transcribed in the months of Shathân through Ramadân $761 / 1360$ was copied from the exemplar containing numerous marginal glosses by the scribe's teacher and his teacher's teacher, thus bringing it very close, if not to the very time when the original was compiled. There is also an old codex, going back to the Gth/13th century or earlier, entitled Sharḅ Fușal Buqràt (ms $7785 / 66$ ) by Ibn Abî Șàdiq, known as Buçrât al'Thànî (d. after 460/1068).

\section{Blacker-Wood Collection}

The Blacker-Wood Arabic, Persian and Urdu manuscripts were gathered almost exclusively by Dr. Wood. Most of the 238 volumes were collected in 1926-27 by W. Ivanow, who provided the collection with a hand-written list. ${ }^{2}$ 'The collection contains some 89 individual compositions in 75 volumes. There are 21 works on Philosophy and Logic, 15 on Grammar and Lexicography, and 12 on Theology, Sufism and Ethics. Other subjects covered are Qur'anic exegesis, Hadith, Figh, Rhetoric, Prose and Poetry, Arithmetic and Astronomy, as well as Natural History and Veterinary Science.

The oldest dated manuscript is a copy of alKashshâf (ms 170) of al-Zamakhsharî (d. 538/1144) transcribed in Dhû al-Hijjah $785 / 1384$. Three other clated manuscripts come from the $9 \mathrm{th} / 15 \mathrm{th}$ century. These are al-Rawd al-fa'iq fi al-mauá iz wa-al-raqa'iq (ms 189) of Abù Madyan Shuayb al-Hurayfish (d. 801/1398), dated Muharram 817/1414; Sharb isagbaji $(\mathrm{ms} 202)$ by an unknown author. executed in Safar 873/1468; and al-Tabdhib fi sharb al-Tahdhib (ms 208), being a commentary by cUbayd Allâh al-Khabîsî on Tabdbîb almantiq wa-al-kalàm ơ Mas ùd al-Taftâzìnî (d.

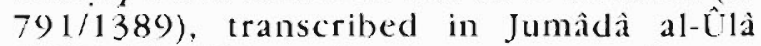
877/1472. This collection, put together in Northeastern India, chicfly at Lucknow, is of great importance for the study of Arabic Indian palaeography.

\section{Islamic Studies Collection}

The Rare Book Section of the Islamic Studies Library houses a relatively small but quite interesting collection of 168 volumes of Arabic, Persian and Ottoman Turkish manuscripts. Most of this collection constitute Arabic codices. There are 112 volumes embodying some 127 individual texts. In subject coverage, it is similar to the Blacker-Wood collection. With almost all disciplines represented, these two collections in many ways complement each other. The disciplines best covered are Jurisprudence ( 34 texts), Philosophy and Theology (27 texts) and Grammar (19) texts). Approximately $85 \%$ of the Arabic collection is of Persian provenance. The remaining $15 \%$ constitute manuscripts which were exccuted mostly by Turkish hands. These manuscripts were acquired in the 1960s and 1970 s from Iranian and European booksellers.

The oldest dated codex is a copy of a gloss (bâshiyab) by Ahmad Khayâlì (d. 870/1465-6) on a commentary (sharb) on al-Aqàid alnasafiyah (ms 112), transcribed in 899/1493-4. This collection also includes a beautifully calligraphed and illuminated copy of a collection of praycrs (ms 42 ), mostly by the famous Sufi master 'Abd al-Qàclir al-jîlànî (d. 561/1167), executed in Shacbàn 1094/1683, and a large-size leaf $(44 \times 28.5 \mathrm{~cm}$.) from a "Kùfî" Qur'an (nss 167), written on parchment supposedly by cAli ibn Ahmad al-Warrâc for Fattimah, the Zirid Princess of Qayrawàn, on 10th Ramadân 410 , i.e., $1020 \mathrm{~A}$.D. This leaf is a gift from the former President of Tunisia, Habil Bourguiba, who visited in the Institute and its library in 1959. ${ }^{3}$

\section{McLennan Collection}

The Mclennan collection, apart from a number of Persian and Ottoman Turkish manuscripts. contains 33 volumes of Arabic manuscripts (i.c., 16 individual works). Among 
the 33 volumes there are 18 copies of the Qur'an, three works on Grammar and Rhetoric, five prayer-books and two works on Sufism. Most of these manuscripts came from Dr. Casey Wood, the others came from various private sources and book dealers, notably from H.K. Monif of New York.

The most notable items in this collection are:

1. Kitâb al-kâmil (ms A2) of al-Mubarrad (d. 285/898), the oldest Arabic dated codex at McGill, transcribed in Rajab 563/1168. It bears two seal impressions of the Bohora Dâcî "Abd al-Qâdir with the date 1258/1842.

2. Kalilah wa-Dimnah (ms A1) of Bidpai, dated Rabî̀ al-Thànî 1055/1645 and containing 95 well-executed miniatures.

3. Jawâhir al-anuâr wa-nasamât al-azhâr (ms A4), a collection of prayers by Mûsâ alMaghribî, calligraphed by an Ottoman calligrapher, Ibrâhîm al-Rudûsî in 1 165/1751-2.

4. Talkhîs al-Miftâb (ms A3) of al-Khatî̀b alDimashqî (d. 739/1338) executed in 960/1552-3 by Ramadân ibn Muhanmad ibn Salmân alTabrìzî and containing four well-drawn miniatures.

\section{ARABIC CALLIGRAPHY}

As mentioned earlier, the Department of Rare Books at the McLennan Library houses a collection of over 200 pieces of calligraphy and single leaves from different manuscripts. This very beautiful and valuable collection includes 82 signed calligraphs and 28 diplomas (ijâzât) issued to calligraphers. Among the fragments there are 15 parchment leaves. Most calligraphs are of the type called qit ah (i.e., single, usually mounted and decorated piece), although there are a number of discarded leaves (mukbraj) and albums (muraqqa ${ }^{c}$ ). They were acquired by $\mathrm{Dr}$. Gerhard R. I.omer (1882-1970), former University Librarian, from Atkinson of London in the early 1920s.

The signed calligraphs represent the following names:

'Abd al-Ghaffâr Baydâ'î Khâvarî. - Nos. AC39 (panel in thuluth, dated 1258/1842-3), AC40 (panel in nastaliq, dated 1258/1842-3).
"Abd al-Halìm Amîr Afandî zâciah (d 1169/1755, Huart, 167-168; Rado, 157-158). - No. AC 100 (qit $a b$, n.d.). ${ }^{4}$

"Abd al-Qâdir al-Hamdî Imâm zâdah (d. $1190 / 1776$, Rado, 174 or $1210 / 1795-6$; Huart, 187). - No. AC 15 (single leaf, n.d).

'Abd al-Rahmân al-Hilmî (d. 1220/1805, Huart, 188; Rado, 187; Inal, 130-131). - No. AC12 (qitrah, n.d.).

"Abd Allâh Yadî Qulalî (Yedikuleli, d 1144/1731-2, Huart, 159; Rado, 136-138). - Nos. AC25 (qit ah, n.d.), AC99 (qit ab dated 1141/1728-9), AC107 (mukhraj, n.d.).

Ahmad Jâwush zâdah, a pupil of Husayn Afandî Khaffâf zâdah. - No. AC88 (qit ah, n.d.).

Ahmmad Khalîl Bâshâ zâdah. - No. AC3 (qițah, n.d.).

Bakr al-Qûnawî. - No. AC95 (single leaf, dated $1161 / 1748)$.

Darwish Ahmad (d. 1127/1715, Rado, 122; Huart, 138). - No. AC84 (qit"ah, n.d.).

Darwîsh 'Alî II (Kuçuk, d. 1128/1715, Rado, 123; Huart, 151). - No. AC18 (qit $a b$, n.d.).

Darwîsh "Alî III - No. AC20 (unmounted fourleaf muraqqa', dated 1201/1786-7).

Darwîsh Ibrâhîm ibn Shacbân Khânah-i Safarlî. - No. AC85 (undecorated qițab, n.d.).

Fayḍ Allâh al-Lam'î̀, Imâm Jâmic Sulaymân in Uskudâr. - No. AC91 (undecorated qif̣ah, n.d.).

Hâfiz Ibrâhîm (possibly the same as Ibrâhîm alShawqî, q.v.). - No. AC17 (qiţah, n.d.).

Hamd Allâh [al-Amâsî, known as Ibn al-Shaykh] (d. 926/1520, Huart, 108ff., $114 \mathrm{ff} ., 137 \mathrm{ff}$; Rado, 49-54). - No. AC155 (mukbraj, n.d., with a note bù mukhraj Hamd Allâb alma'rûf bi-Ibn al-Shaykh).

Hasan al-Rushdî (d. 1205/I790, Jabartî, II, 116-117) - No. AC156 (an ijâzab, with a chain of authorities going back to "Alî ibn Abî T’âlib and Muhammad, given by "Abd Allâh al-Anîs al-Mawlawî, dated 1157/I744-5. Followed by twelve other ijazât granted by Muhammad al-Nûrî, Ismâcîl al-Zuhdî, Hasan al-Diyầî, Ahmad ibn Ismâî̀l al-Afqam, 'Ali al-Mâlikî, Ibràhîm al-Riwaydî, Ahmad Abû al-'Iž alShanawânî, Muhammad al-Azharî, 
'Abd Allâh, a pupil of al-Anîs, Ahmad alMukhliș, Sulaymân, a pupil of al-Ḍiyầi and Muḷammad Najîh Șûyûljî zâdah). ${ }^{5}$

Husayn al-Jazầirî (d. 1125/1713, Muràdì, II, 55-56; Zabìdî, 94). - Nos. AC51 (qip̣ah, dated $1131 / 1718-9$ !); AC52 (undecorated qifab, dated [1]119/1707-8); AC53 qi! ah, dated [1]114/1702-3).

Husayn ibn Ramadân (d. 1 157/1744, Rado. 145 or 1152/1739; Huart, 162-163). - No. AC37 (qit $a b$, n.d.).

lbrâhîm al-Shawqî (also known as Hâfị̣ Ibrâlîim, d. 1245/1829, Huart, 192; Rado, 202). No. $\Lambda C 163$ (Sûrab 78-114, dated Shawwâl, $1235 / 1820)$.

Ibrâhîm ibn Ismâ'îl al-Mu'nis. - Nos. AC72 (11 unmounted leaves, dated $1257 / 1841-2$ and 1262/1845-6); AC70 (unmounted muraqqa of four leaves, dated 1261/1845).

Ismầìl al-Zuhdî I (d. 1144/1731, Huart, 160; Rado, 135-136). - No. AC43 (qirah, n.d.).

Ismâ‘îl al-Zuhdî II (d. 1221/1806, Rado, 186-188; Huart, 188). - Nos. AC47 (qitcah, dated 1205/1790-1); AC135 (two leaves, dated 1200/1785-6).

Ismâ'îl al-Zuhdî (either 1 or II). - Nos. AC44-AC46, AC49-AC50, AC.160, all undated).

Ismâcîl ibn 'Alî. - No. AC98 (qiț ah, n.d.).

Khayr al-Dìn. - No. AC94 (unmounted qit ab. dated 1303/1885-6).

Mahmûd Jalâl al-Dîn (d. 1245/1829), Rado, 199-200; Huart, 191-192). - Nos. AC26 (qit $a h$, n.d.); $\mathrm{AC} 27$ (one leaf, n.d.); AC29 (large pancl in thuluth, n.d.); AC30 (large panel in thuluth, n.d.).

Muhammad al-Hilmî. - No. AC13 (undecorated qitcab, n.d.).

Muhammad al-Nùrî [al-Maçdisì] (d. 1 162/1748-9), Kurdî, 251; Zabîdì, 94 or Rajab 1163/1750, according to a marginal note on $\mathrm{AC} 35)$. Nos. AC33 (qitah, n.d.); AC34 (qitah. dated 1128/1715); AC35 (qitcab, $1163 / 1749-50)$.

Muhammad Amìn Afandì. - No. AC157 (Sürah 77, followed by two ijazàt, given by Muhamnad Nùrî and Muhammad al-Sa'id Mustaqîm zàdah, dated 1183/1769-70) (Figure 1).
Muhammad 'Arab zâdah (d. 1127/1715, Huart, 151). - No. AC90 (qit $a b$, n.d.).

Muhammad Bayầzìd zâdah. - No. AC96 (unmounted qit'ah, n.d.).

Muhammad Fakhrì Afandî. - Nos. AC31 (qiẹah, with two ijâzât given by Muhammad alKhulûsî and al-Sayyid Hamdî, dated 1263/1846-7) (Figure 3); AC32 (qitab, with two ijâzât granted by Muhammad alWașfî Dầi Aḥmad, dated 1263/1846-7) (Figure 2)

Muhammad Ghàlib Fawzî Afandî. - Nos. AC58 (qił $a h$, with three ijâzât given by Muștafâ al-Hilmî damâd al-Sukûtî̀, "Alî al-Hamdî and Hâfiz Husayn al-Lutfin, a pupil of Mustafâ al-Hilmi, dated 1258/1842-3) (Figure 5); AC59 (qițah, with three ijâzât given by Muhammad Tâhir, known as Khalîfat Mustafầ al-Hilmì damàd Ibràhìm alSukûtî, Muhammad Amîn al-Dhihnî, a pupil of Kabâjì zàdah and Ya qûb Hakkî, a pupil of Mustafâ al-Hilmî. All dated 1258/1842-3) (Figure 4).

Muhammad ibn Mahmûd. - No. AC42 (unmounted three leaves, dated $1113 / 1701-2)$.

Mulaammad ibn Muhammad. - No. AC101 (qit ab, n.d.).

Muhammad Mu'nis zâdah (d. 1318/1900. Azzâwî, 290). - Nos. AC64 (unmounted qitab, dated 1286/1869-70); AC68 qit ab, dated 1286/1869-70).

Muhammad Qâsim 'Tabrîzî. - Nos. AC60 (panel in nastaliq, dated 1282/1865-6); AC61 (panel in nastalîa, n.d.); AC62 (panel in nastalia, n.d.); AC158 (seven leaves from a muraqqa , dated 1284/1867-8).

Muhammad Râghib Afandì. - No. AC97 (qit'ah, with an ijazah given by Muhammad 'Atâ', a pupil of Wașî̀ Afandî, dated 1201/1786-7) (Figure 7)

Muhammad Râsim (d. 1169/1755, Rado, 155-156; Huart, 168). - No. AC87 (qitab, n.d.).

Muhammad Shakar zàdah (d. 1166/1752, Rado, 151-152). - Nos. AC36 (qitah, n.d.); AC54 (qit ah, n.d.); AC55 (qit ab, n.d.).

Muhammad Shahrî (d. 1153/1740, Rado, 141; Zabîdî, 94). - Nos. AC14 (qițah, n.d.); AC21 (qit'ab, dated 1115/1703-4). 


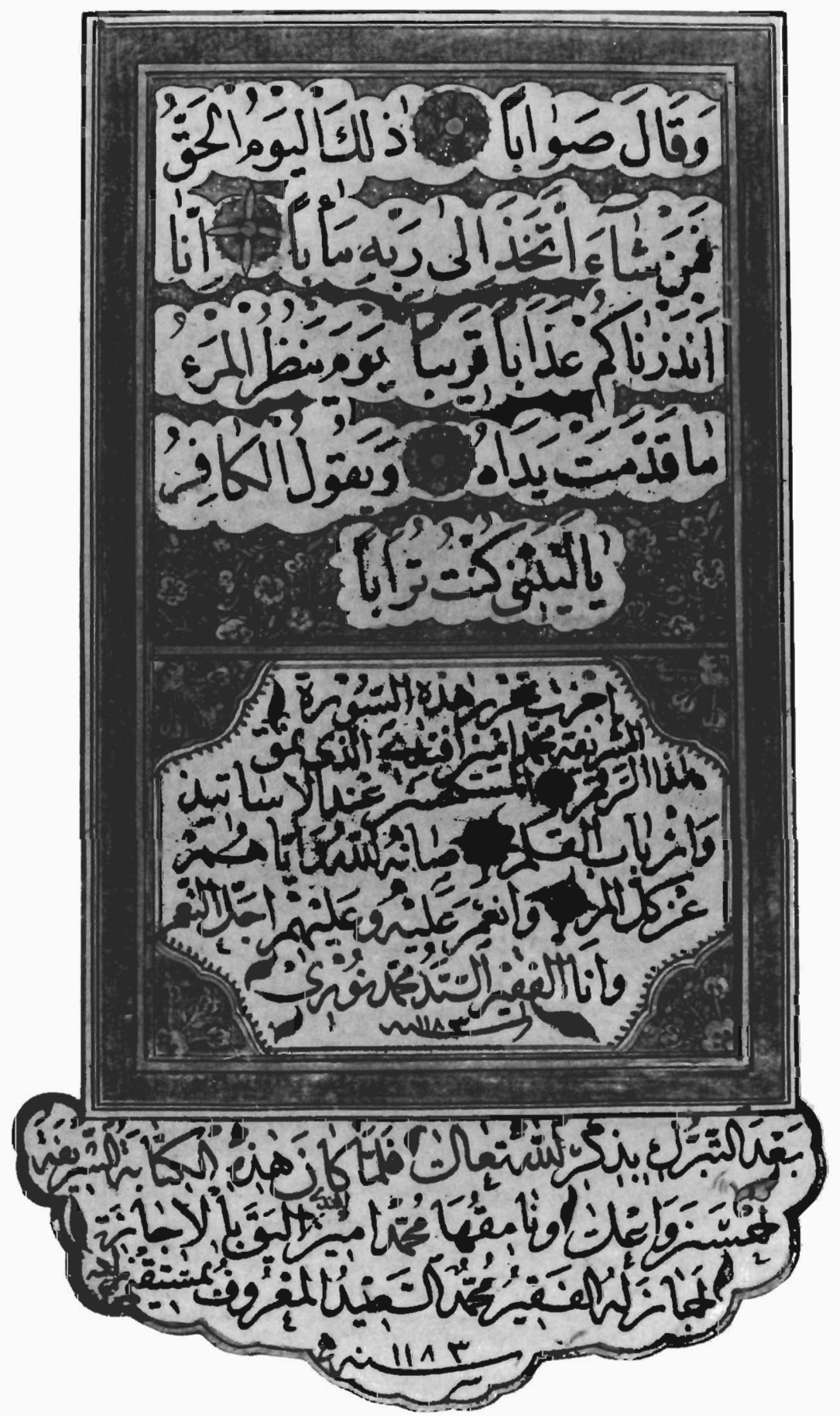

Figure 1. Two diplomas awarded to Muhammad Amîn Afandî (AC157). 


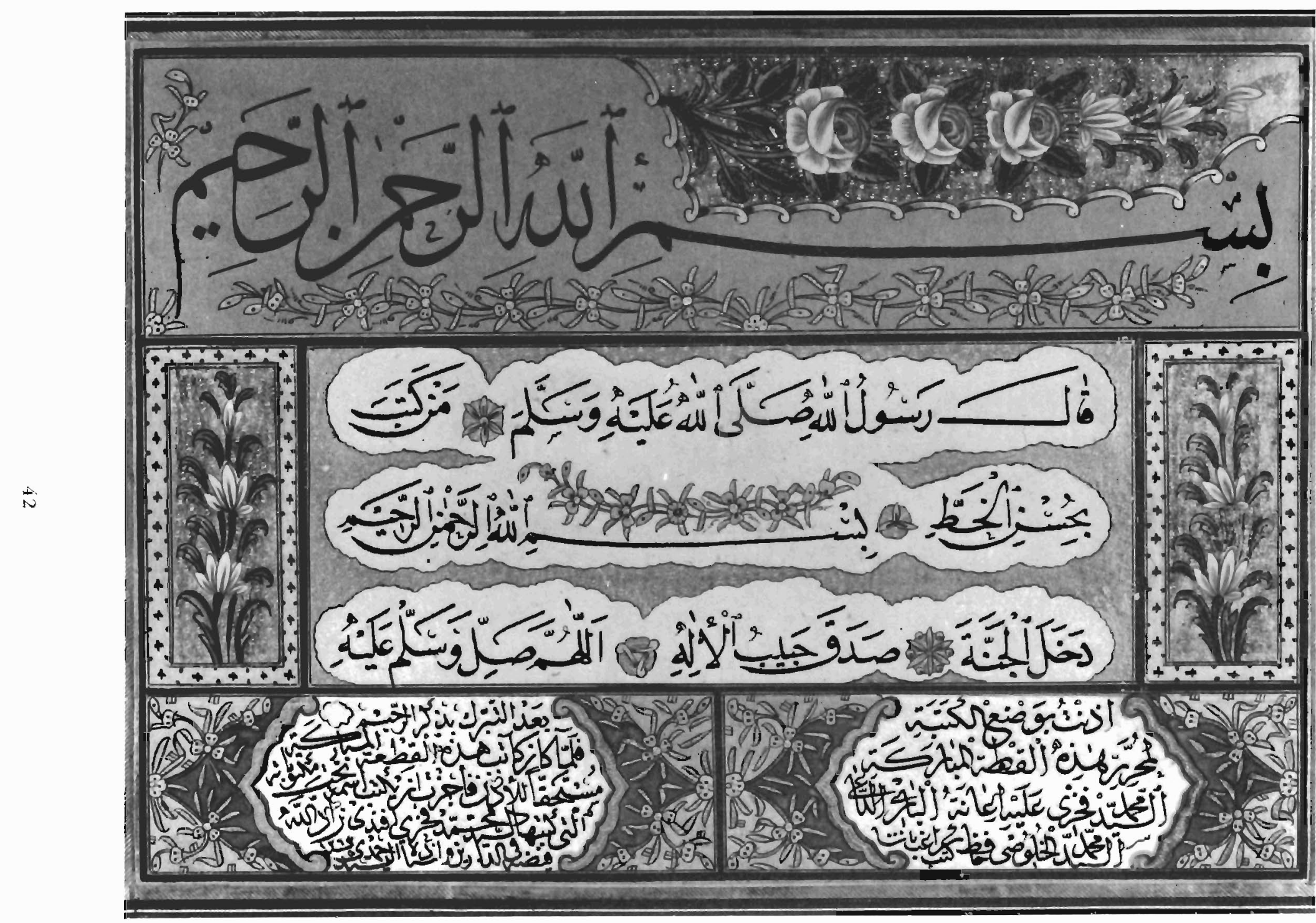

Figure 2. Two diplomas granted to Mụ̣ammad Fakhrî Afandî (AC32). 


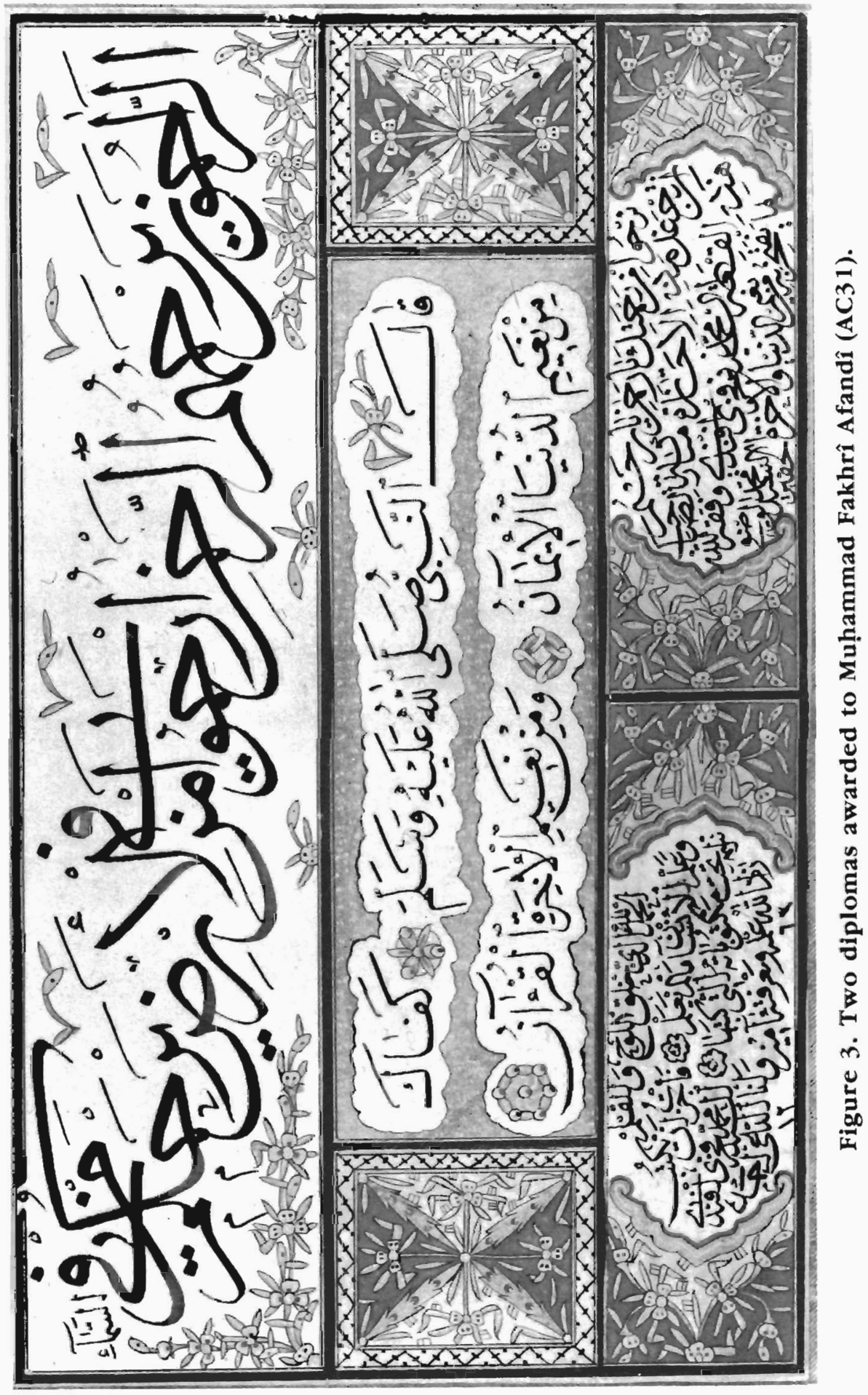




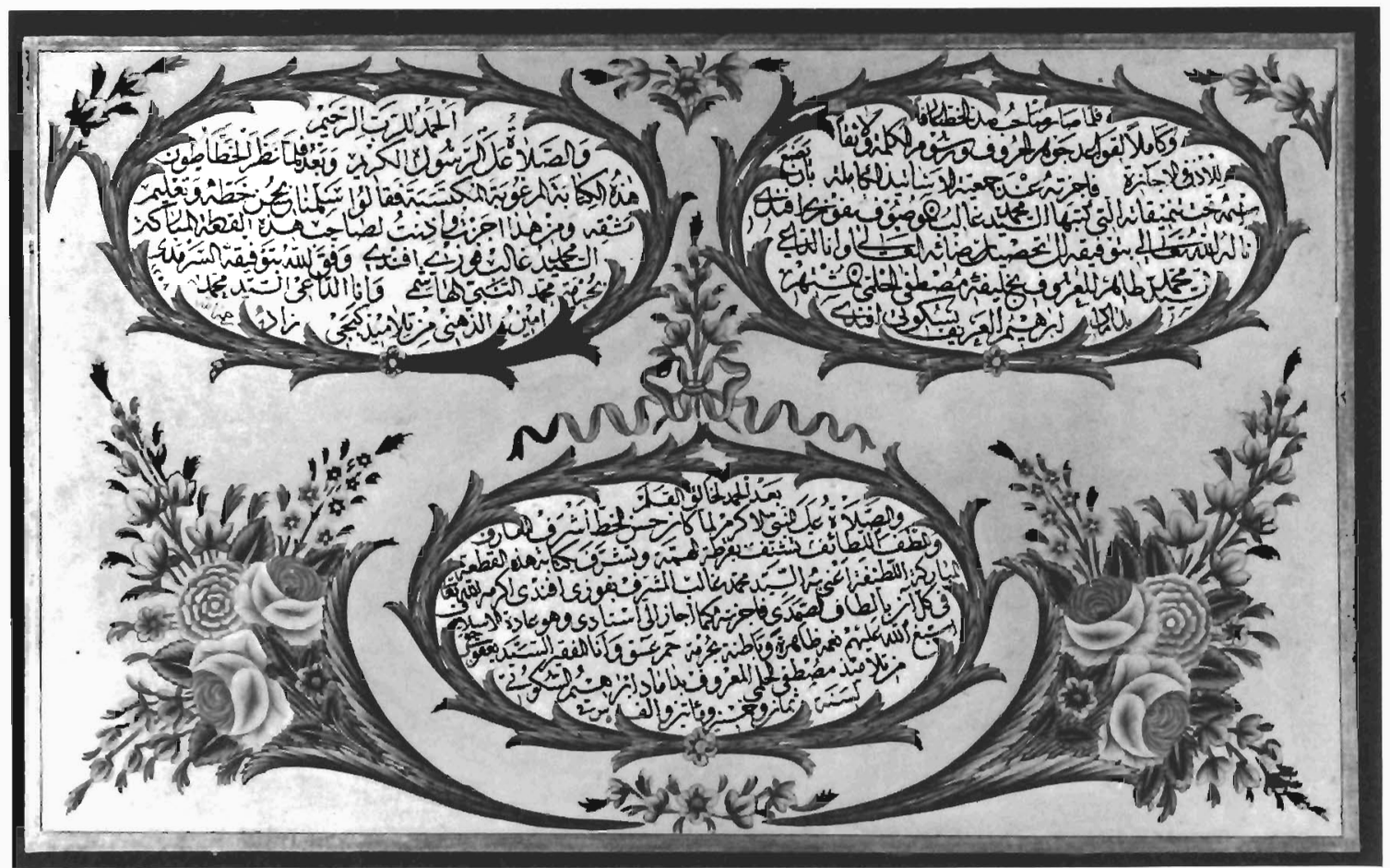

Figure 4. Three diplomas granted to Mụammad Ghâlib Fawzî Afandî (AC59).

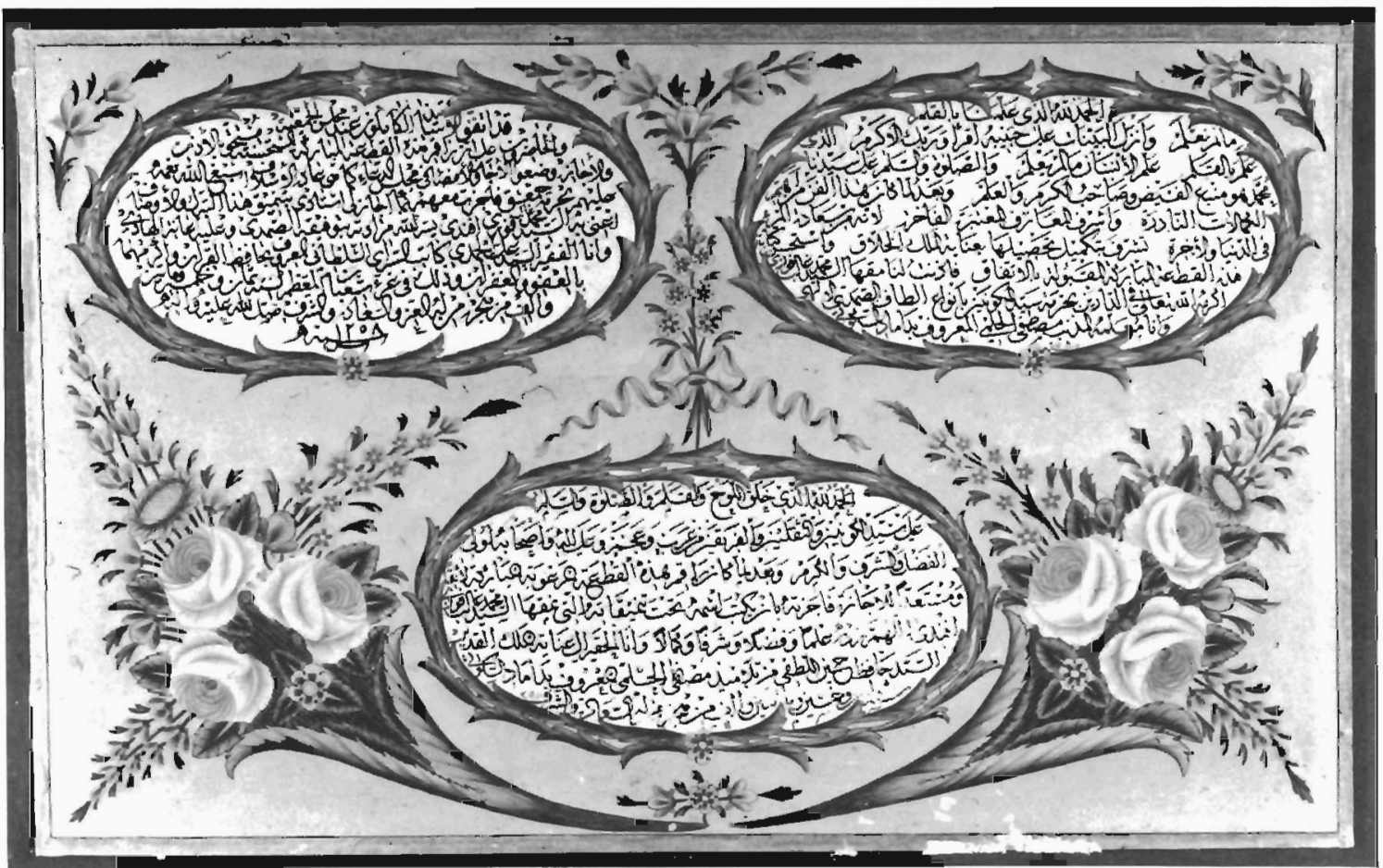

Figure 5. Three diplomas awarded to Muhammad Ghâlib Fawzî Afandî (AC58), 


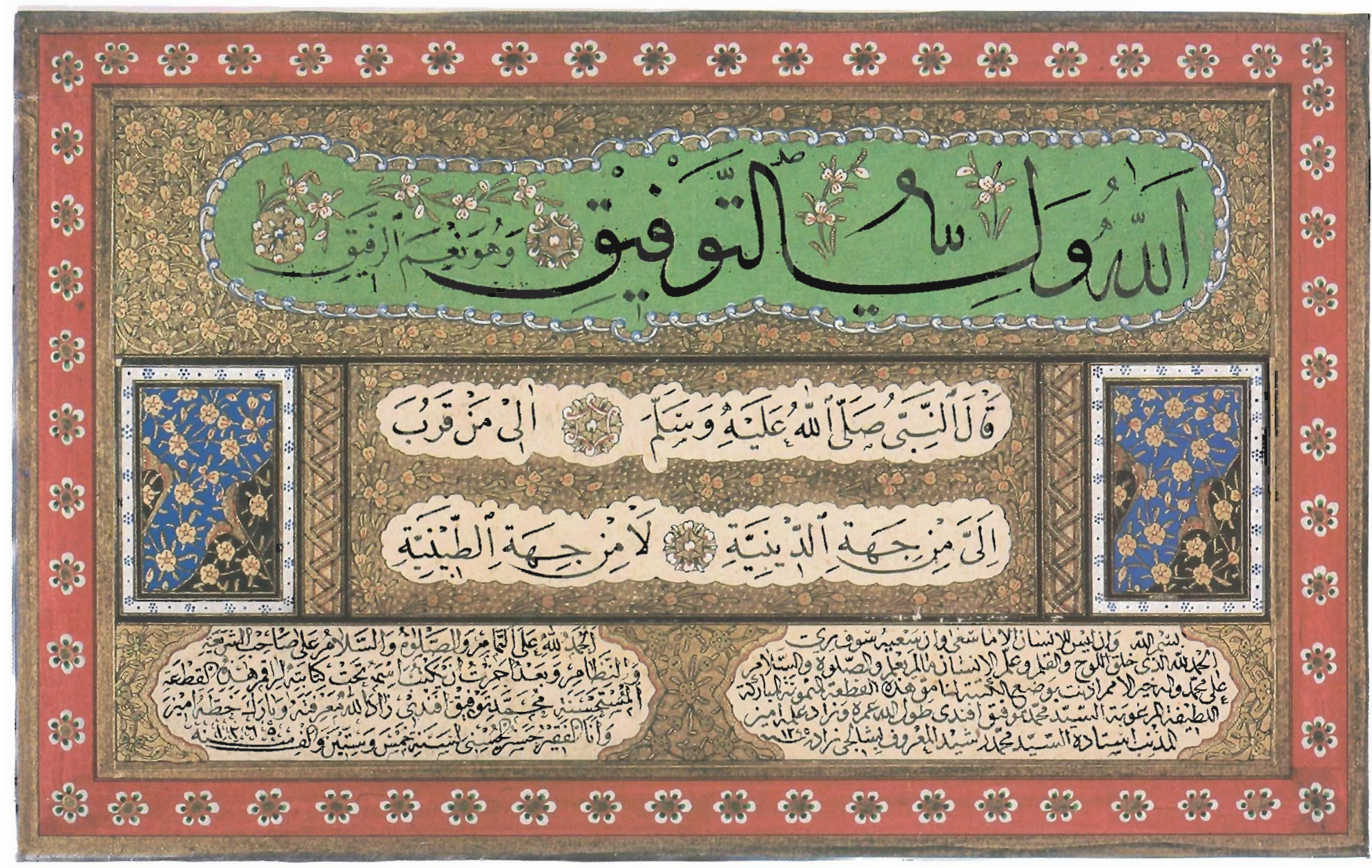
Muhammad Tawfíq Afandî (AC57). 


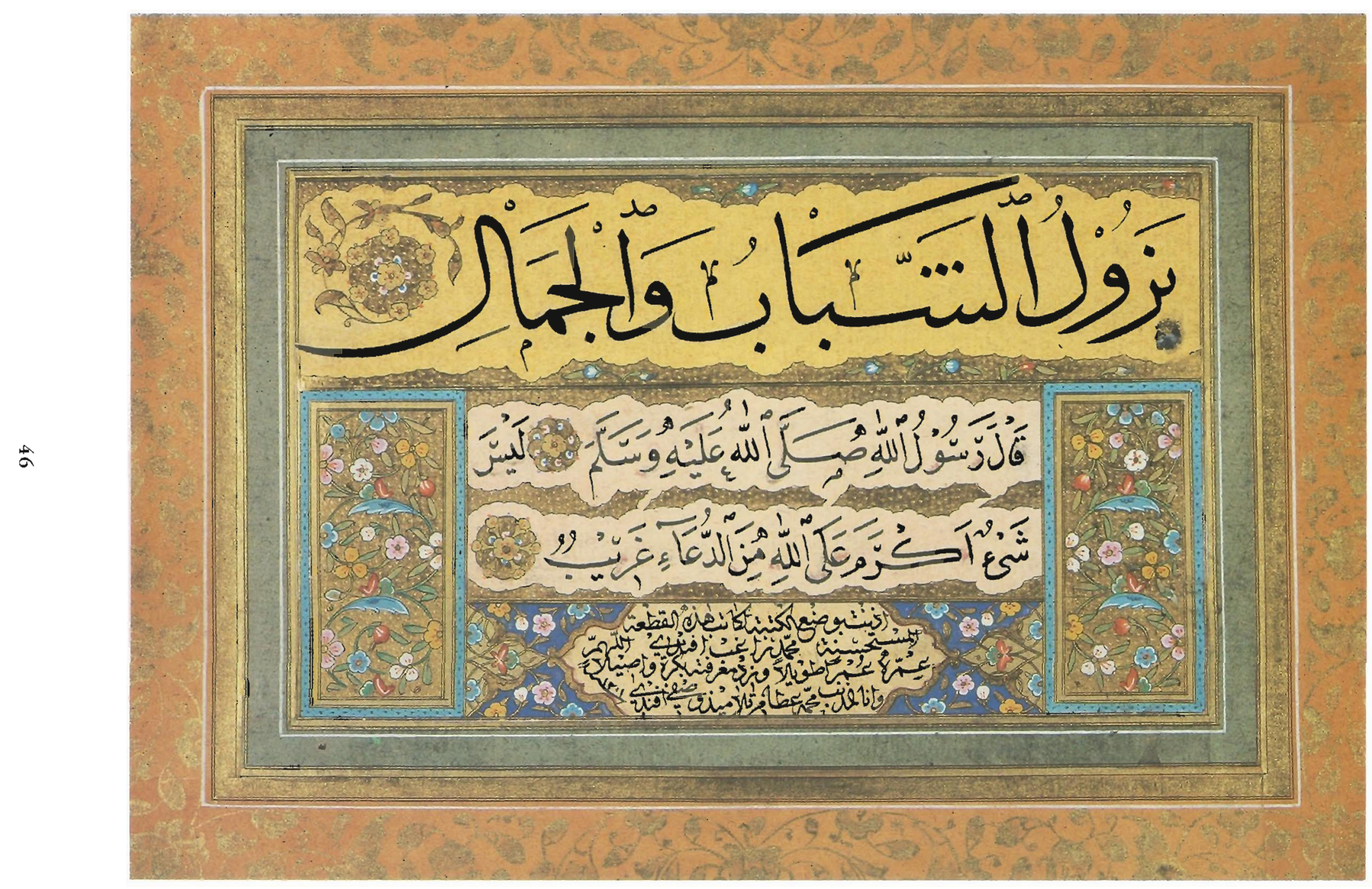

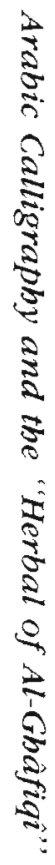

Figure 7. Calligraphic panel with a diploma given to Muhammad Râghib Afandî (AC97). 


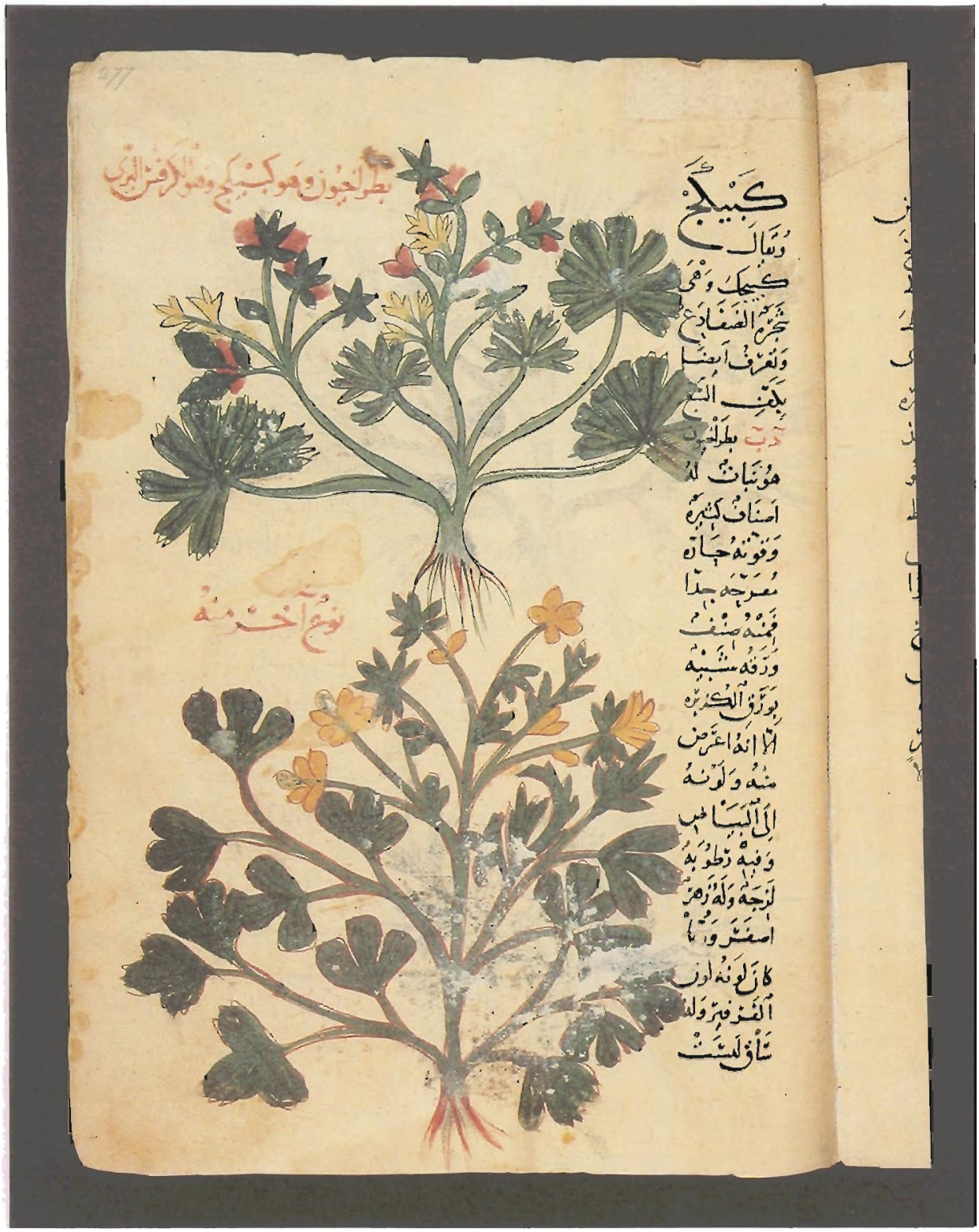

Figure 8. Folio 277 a from the Osler codex depicting two kinds of kabîkaj (ranunculus asiaticus). 


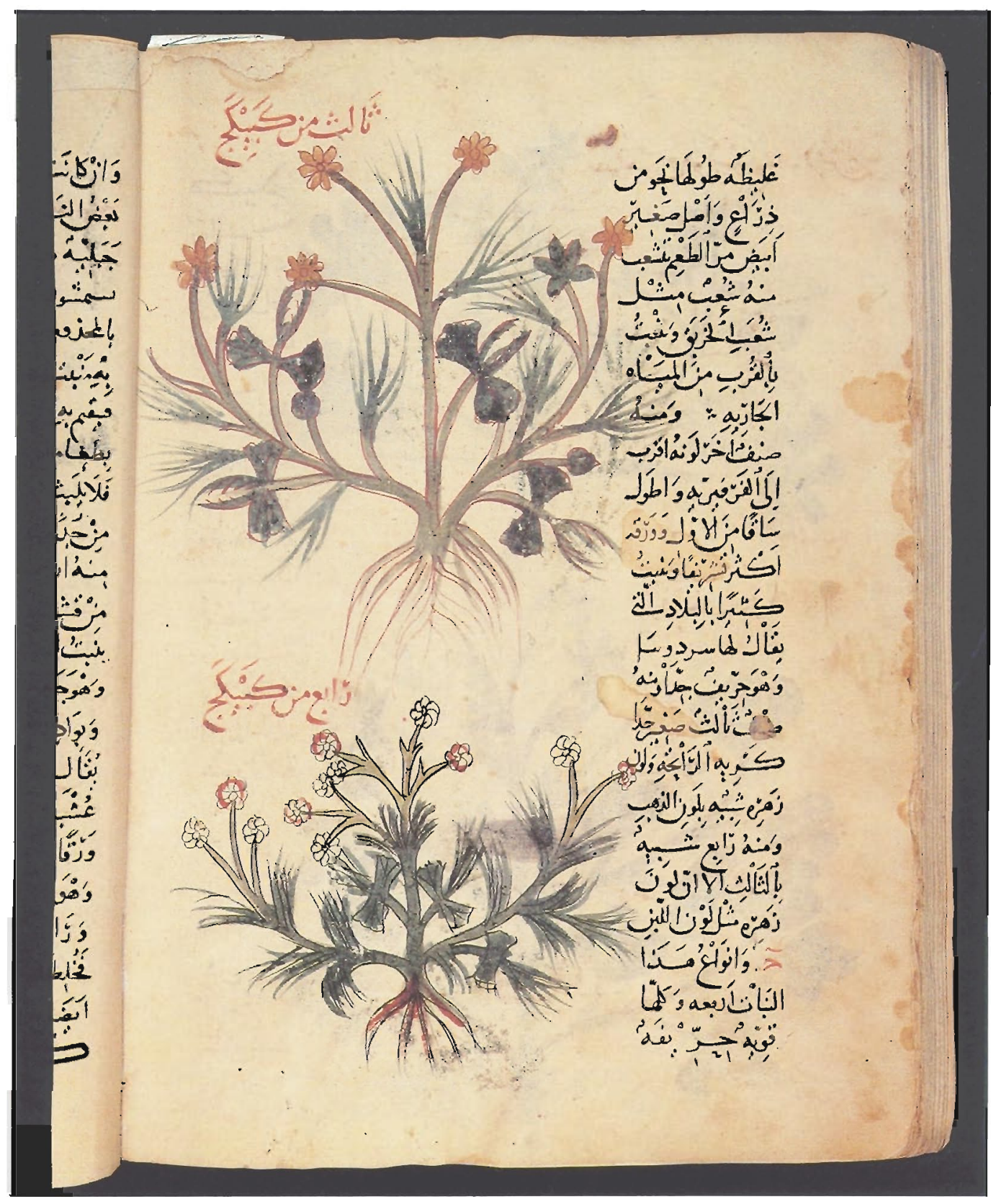

Figure 9. Folio $277 \mathrm{~b}$ from the Osler codex depicting two additional kinds of kabîkaj (ranunculus asiaticus). 
Muhammad Tawfìc Afandì. - Nos. AC.57 (qitcab, accompanied by two ijazat granted by Muhammad Rashìd Shâlijì zâdah and Husayn al-Husnî, dated 1265/1848-9) (Figure 6).

Muștafầ "Alî zâdah (a pupil of Shughlì Dadah). No. AC89 (qitcab, dated 1137/1724-5).

Muștafâ cIzzat (dl. 1293/1876, Rado, 216-218). Nos. AC16 (qitah, n.d.); AC4l (four unmounted leaves, dated 1282/1865-6 and [12]83/1866-7).

Muștafà Mu'adhohin zâdah (a pupil of 'Abd Allâh al-Hâshimî). - No. ACO2 (qiṭah, n.d.).

Muștafâ Nùrî. - No. AC:IO4́ (unmounted lealf, n.d.).

Mustafà Ràqim (d. 1241/1826, Rado, 196-199; Huart, 191). - No. AC63 (qițah, n.d.).

Sulaymân Hikmatî (Inal, [372-373]). - No. AC93 (qit $a b$, n.d.).

Tạsìn al-Husnî, - No. AC:165 (large panel in thuluth, n.d.).

Tawfìcî (a pupil of 'Uthmân Afandî). - No. AC:162 (four-leaf muraqqa', dated $1225 / 1810)$.

Umar al-Wașii (d. 1240/1824, Rado, 195-196; Huart, 190). - No, AC 159 (nineleaf muraqqa', dated 1220/1805-6).

'Uthmân damâd Ibrâhìm al-'Afîf (d. $1120 / 1805$, Rádo, 185). - No. ACIO2 (single leaf, n.d.).

'Uthmân Hâfiz al-Qur'ân (also known as Hàfiz 'Uthmân, đ. 1110/1698, Rado, 109-114: Huart, 143-144). - Nos. AC73 (qil ab, n.d.); AC.74 (panel in thuluth, n.d.).

'Uthmàn ibn Darwîsh Muhammad Aghâ al-Ard Rûmî [of Erzurum]. - No. AC164 (Sirab 18 , n.cl.).

Yahyâ Afandî (possibly al-Sayyid Yahyà, d. 1198/1783, Rado, 175). - No. AC9 (qiț ah, n.d.)

\section{THE "HERBAL" OF AL-GHÂFIQî}

The illustrated Arabic codex, the "Book of simple drugs" or Kitab fi al-aduiyab almufradab, was compiled by the Andalusian pharmacologist and botanist Abù Jacfar Ahmad ibn Muhammad al-Ghâfiçî (d. 560/1 165). ${ }^{6}$ Not much is known about the author's life except that his family came from the region of Cordova where he is likely to have practiced medicine and pharmacology. His father Muhammad ibn Qassùm was a scholar and oculist. According to Ibn Abî Usaybicah, a historian of Arabic medicine, al-Châfiqî was the greatest scholar of his time in this domain. His book of simple remedies is a unique encyclopedia. ${ }^{7}$

The manuscript, originally believed to be part of an Arabic translation of De Materia medica of Dioscorides, was purchased in Iran for Sir William Osler, then Regius Professor of Medicine at Oxford University, in 1912. It was accuired together with a copy of the work of Dioscorides and the price paid for the two manuscripts was 25 pound sterling, only five pounds more than the offer made by the British Museum. Osler intended to give this manuscript to the Bodleian Library, but when Dr. W.W. Francis, a cataloguer of the Osler collection and later the first Osler Librarian, discovered that it was not the work of Dioscorides, he successfully claimed it for the Osler Library. Oster had his whole library catalogued before he bequeathed it to Mcciill University. ${ }^{8}$

The present volume constitutes part one (aljuz' al-auwal) of the original work, in which all entries (mainly names of plants, but atso some drugs and animals) had been arranged in alphabetical order. As was the practice in those days, the author used the alpha-numeric notation $(a b j a d)$. It is important to bear this in mind as the sequence of letters in this notation is not only different from the present day arrangement of the Arabic alphabet but also varies in places from its castern (mashriqi) version. Our manuscript, being the first volume of al-Ghâfiqî's work, covers the letters alif through kaff, but having in between $b \hat{a}^{\prime}, j i m$, dal, $b a^{\prime}, w a w, z a y, b \hat{a}^{\prime}, t \hat{a}^{\prime}$, and $y \hat{a}^{\prime} .{ }^{9}$

The "Herbal" of al-Ghâficîi is an example of a well-planned piece of work. Since it is based on the works of Dioscorides (Dîsquirìdis) and Galen (Jâlìnùs), he refers to these two main sources by using abbreviations: dàl for Dioscorides and jim (unpointed) for Galen. These abbreviations (rumuz) are followed by the number of the chapter (maqalab) from which a given piece of information was obtained. Thus, 
for example, dâl bâ' means Dioscorides chapter 2 and jîm wâu, Galen chapter 6. Other, later sources are also mentioned, usually by referring to the name of the author. Each letter sequence, which forms a chapter (bâb) is followed by a summary giving meanings (sharb), etymology and synonyms of the plants. ${ }^{10}$

As far as we know, only three or four other copies of this work are extant." This manuscript, preserved in the Osler Library, is a rare example of Arabic art. It numbers 284 folios (including two fly leaves) and its measurements are approximately $25 \times 18 \mathrm{~cm} .(20.5 \times 13.5 \mathrm{~cm}$., for the written area) and 23 lines per page. It is written on thick Oriental paper of wove texture, in a very elegant hand, which can be characterised as Old Naskb (al-Naskb alQadim), similar to the al-Naskb al-Faddâb or al-Waddâb, known as an "all revealing," clear Naskb. ${ }^{12}$ The text is partly vocalized and the unpointed letters (al-burûf al-mubmalab) are distinguished either by a small caret (v) or a miniature version of the same letter (e.g., $b \hat{a}^{\prime}$ and cayn). Some of the main features of this hand are: a flat and thick stroke of the final lam, the "tail" on the alif of prolongation, the serif (tarwis) on such letters as alif, lam, dâl, nûn (particularly in chapter headings), and the occasional lack of a bar over the letter kâf. The presence of tarwîs is unusual for in most cases a Naskb hand is devoid of it. The codex contains 475 entries and 367 coloured drawings, mainly of plants, but also of animals and some drugs. Among the plants we find four unique drawings of Ranunculus Asiaticus ("little Asiatic frog") called Kabikaj (fols. 277a and 277b, Figures 8, 9.) This plant, and later just its name, was used for the preservation of manuscripts. ${ }^{13}$ The volume is richly rubricated and its chapter headings and lemmata executed in black ink in bold letters (taghliz). The end of a paragraph or section is indicated either by $b \hat{a}^{\prime}$ and $y \hat{a}^{\prime}$ (for intabâ, i.e., literally "it ended") or an open circle with a dot in the middle or three shaded carets in the form of a triangle or all three marks together (as e.g. on fol. 53b).

The name of the copyist is not given and the date reads most probably Sha'bân 654, i.e., August $1256 .{ }^{14}$ According to Prof. M. Meyerhof, who was the first to study this manuscript in some detail, the handwriting and drawings can almost without doubt be attributed to an artist from the Baghdad school which flourished in the first half of the thirteenth century until the destruction of Baghdad by the Mongols in 1258 A.D. "A Baghdad," says Meyerhof, "on en a certainement écrit une ou plusieurs copies calligraphiées pour des personnes de marque et on les a ensuite fait illustrer par des artistes cirâqiens. Le manuscrit de Montréal est très probablement un des premiers ou mème le premier en date - et à cause de la catastrophe de Baghdad aussi un des derniers - exemplaires du Gâfiqi illustré." Is This, and the fact that the other surviving manuscripts appear to be inferior, adds to the importance of the Osler manuscript.

Looking at the text itself one soon notices that the manuscript was collated. The marginal corrections constitute mainly omissions/ insertions. They are indicated by placing a stroke, between the words in the body of the text, which curves upwards in the direction of the margin where the omission is placed. If the omission consists of one or two words it is written on the level of the line from which it is missing. If, however, it is longer, it descends or ascends from the line of omission. The end of an omission is indicated by the word sabpa, meaning it is correct, followed, sometimes, by the next word in the text, which is then crossed out. Only a few variants are to be found in the margins. They are indicated by writing the number two above the relevant word in the text and the same number plus the letter $k h \hat{a}^{\prime}$ (for nuskbab ukbrâ, another copy) above the word in the margin. ${ }^{16}$

The red leather covers with on-laid medallions and pendants are of a more recent date. In view of the fact that there is no envelope flap (lisân) and the fly leaves are made of European wove paper, the present binding is likely to have been supplied at the beginning of the nineteenth century. It is at this stage also that the first eight leaves were added. A number of illustrations are damaged, mainly due to the offsetting of ink. There is also some loss of text caused by trying to separate the leaves which got stuck together. Furthermore, as a result of mindless rebinding, many folios are out of order. According to Professor Meyerhof, who examined a photostat of this manuscript, the sequence should be as follows: fols. 2-9, 10-11, $19,12-18,20-41,42-43,44-110,120,112-119$, 
$111,121-122$, one or two folios missing, 123-141, 143, 142, one leaf missing, 144-147, $149,148,151-253,274-277,254-267,271,273$, $279,278,268-270,282,280-281,283 .^{17} \mathrm{He}$ does not mention, however, fols. 150 and 272 , which should follow nos. 148 and 271 respectively. One of the reasons for this confusion may have been the fact that the original catchwords were placed only at the end of each quire of 10 folios.

The original manuscript must have existed in an acephalous form for some time. This can be inferred from the title on fol. $10 \mathrm{a}$ in the head margin; it reads: Tibb-i Qâfiq $\hat{\imath}($ !) (The medicine of al-Ghâfiqî). The name Ghâfiqî is written with and unpointed qâf (pronounced in Persian as $\left.g h \hat{a}^{\prime}\right)$. This, and the lack of the definite article before the name is a good pointer to the manuscript's Persian connection. If we accept Professor Meyerhof's theory that it originated in Baghdad, then it must have travelled to Iran, where it stayed for several centuries, before it was shipped to Oxford and later to Montreal. The same folio bears two seals: one oval with the legend wa-salàm calà Ibrâbîm (and may peace be upon Ibrahim), dated 1051 A.H., i.e., 1641 or 1642 A.D. and belonging to someone called Ibrâhîm or "Alî Ibrâhîm; the other, placed in the left hand margin and repeated on fol. 283 a reads Muhammad Jamâl al-Dîn alHusaynî with a date 1080 (?) A.H., i.e., 1669 or 1670 A.D. These two names being typical of the Shicite milieu place us firmly on the Persian ground. Of two other seals found in the manuscript one (fols. 119a, 127b and 128a) has an inscription tawakkaltu 'ala Allâb (I have put my trust in God) and the other (fol. 283a) has been entirely erased. In addition, fol. $283 \mathrm{~b}$ bears a note recording several historical events around $815(?) / 1412$ involving three important cities: Samarqand, Herat and Baghdad. Beneath this note there is a chess score (bisab alshatranj) and in the lower end of the folio there is a barely visible date $868(?) / 1463$ or 1464 , which could refer to the writing of the abovementioned statements.

Even though used extensively by Ibn al-Baytâr for the compilation of his $J a m i c$ and abridged by Abû al-Faraj, the work of al-Ghâfiqî has never been edited, and only a few illustrations from the Osler codex have been reproduced. Yet this particular work and its copy preserved at McGill surely deserves a much greater attention on the part of historians of medicine and art.

\section{CONCLUSION}

This brief survey of Arabic manuscripts in the collections of McGill University shows a great diversity of texts, many of which have never been explored by researchers. The Arabic calligraphy and the book of al-Ghâfiqî have been selected as outstanding examples of beauty and rarity to be found in these collections. There are other treasures and a host of, what some might term as, ordinary codices: copies of well-known works which do not add much to our knowledge of different Islamic disciplines. They illustrate, however, a tradition of copying and correction, learning and teaching. Their beauty lies not in the variety of colours but often in the neatness and clarity of the hand. 


\section{Notes}

I am grateful to Dr. Richard Virr, the Manuscript Curator in the Department of Rare Books, McLennan Library, Dr. Faith Wallis, Head, Osler Library and Miss Eleanor MacLean, Head, Blacker-Wood Library, for their assistance.

1. A description of the four collections of Islamic manuscripts at McGill University can be found in Thomas J. Martin's North American Collections of Islamic Manuscripts (Boston: G. K. Hall, 1977): 86-90. The information, however, is inaccurate. A complete and more accurate picture of these collections will only emerge once they have been properly catalogued. A Union Catalogue of Arabic Manuscripts is now being planned for future publication by Adam Gacek. Some of the manuscripts in the Osler collection were originally described in Bibliotheca Osleriana, $a$ Catalogue of Books Illustrating the History of Medicine and Science Collected, Arranged, and Annotated by Sir William Osler, Bart. and Bequeathed to McGill University (Montreal: McGill Queen's University Press, I969), i.e., mss $449,450,462,463,464,465,478,7508$, and 7571 , as well as 7785 which is a list of Persian, Arabic and Hindustani medical manuscripts presented in 1927 by Dr. Casey A. Wood and taken from a tabulated list drawn up by $W$. lvanow.

2. The original descriptions of these manuscripts, complete with an introduction and indexes, are preserved in the Blacker-Wood Library under the no. ZE.W 852 . There is also a typescript of 36 pages entitled Annotated Catalogue of the Casey A. Wood Collection of Persian, Arabic and Hindustani Manuscripts by Wladimir lvanow (Bombay: 1927). This document contains a preface and a list of rare works in the collection with references. A similar list prepared by W. J. Watson, the first Librarian of the 1slamic Studies Library, can be found in A Dictionary Catalogue of the Blacker-Wood Library of Zoology and Ornithology (Boston: $G$. K. Hall, 1966) 9: 681-684.

3. A Handlist of Arabic Manuscripts in the
Islamic Studies Library, McGill University prepared by the author of this paper is available for consultation in the library.

4. For biographical details of calligraphers see the following references:

Al-"Azzâwî, "Abbâs. "Al-Khatt wa-mashâhîr alkhattâtîn fî al-watan al-'arabî," Sumer 38. 1/2 (1982): 284-302.

Huart, Cl. Les calligraphes et les miniaturistes de l'Orient musulman. Paris: Ernest Leroux, 1908.

Inal, Mahmud Kemal. Son battatlar. Istanbul Maarif Basımevi, 1955.

Al-Jabartî, "Abd al-Rahmân. Ta'rîkh 'ajâ'ib alâthâr fí al-tarâjim wa-al-akbbâr. Beirut: Dâr al-Fâris, n.d., $3 \mathrm{v}$

Al-Kurdî, Muhammad Tâhir. Ta'rîkh al-khaț al'arabî wa-âdâbubu. al-Matbacah alTijârîyah al-Hadîthah bi-al-Sakâkînî, 1939.

Al-Murâdî, Muhammad Khalîl. Silk al-durar fi $a^{c} y a ̂ n$ al-qarn al-thânî̀ 'ashar. Cairo: alMatba'ah al-Mîrîyah al-ĉ̂mirah bi-Bûlâq, 1874-83. $4 \mathrm{v}$.

Rado, Sevket. Türk hattatlart. Istanbul: Yayın Matbacılık Ticaret, n.d.

Al-Zabîdî, Muhammad Murtadâ. "Hikmat alishrâq ilầ kuttâb al-âfâq," Nawâdir almakbtututât, ed. "Abd al-Salâm Hârûn. (Cairo: Matha'at Lajnat al-Ta'lîf wa-alTarjamah, 1954) 5: 50-99.

5. For an analysis of this work, see my "The diploma of the Egyptian calligrapher Hasan alRushdî," Manuscripts of the Middle East 4 (1989- forthcoming).

6. The title of this work has been taken from the preface. The colophon, however, refers to it as Kitâb al-Ghâfiqî (The book of al-Ghâfiqî). For biobibliographical information see C. Brockelmann, Geschichte der arabischen Litteratur (Leiden: E. J. Brill, 1937-49) 1:643 and SI:89 I; M. Ullmann, Die Medizin im Islam (Leiden: E. J. Brill, 1970):276-277; "Al-Ghâfikî̀," Encyclopaedia of Islam, new ed. 1960-, suppl., fasc. $5-6$

7. See his 'Uyûn al-anbâ' fì tabaqât alatibbà', ed. Nizâr Riđ̣â (Beirut: Dâr Maktabat alHayâh, 1965):500-501. 


\section{Arabic Calligraphy and the "Herbal of al-Ghâfiq⿳亠丷厂"}

8. This information has been extracted from the letters written by W. Osler, A. Cowley (of the Bodleian Library), J. H. Bill (an official in the British Residency in Bushire, Iran, who acted as a link between $\mathrm{A}$. Cowley and the owner of the manuscript, Dr. M. Saceed), W. W. Francis and appended to this volume. The description of the manuscript of Dioscorides can be found in B. W. Robinson and Basil Gray, The Persian Art of the Book, catalogue of an exhibition beld at the Bodleian Library to mark the Sixth International Congress of Iranian Art and Archaeology, (Oxford: Bodleian Library, 1972): 9-10, pl. 1.

9. "Abdjad," Encyclopaedia of Islam, new ed., 1960-.

10. For a more detailed analysis of the contents of the work of al-Ghâfiqî see M. Meyerhof, "Études de pharmacologie arabe tirées de manuscrits inédits. III. Deux manuscrits illustrés du 'Livre des simples' d'Ahmad al-Gâfiqî, "Bulletin de l'Institut d'Égypte 23 (1940-41): 13-29, 3 plates.

\section{Ullmann, Medizin: 276.}

12. See Muhammad ibn Hasan al-Tîbî, Jâmi mabâsin kitâbat al-kuttâb, ed. Șalâh al-Dîn alMunajjid (Beirut: Dâr al-Kitâb al-Jadîd, 1962): 63-67.

13. See my "'The use of 'kabîkaj' in Arabic manuscripts," Manuscripts of the Middle East 1 (1986): 49-53, as well as James W. Pollock, "Kabî:kaj to book pouches: library preservation magic and technique in Syria of the 1880's and the 1980's West," MELA Notes 44 (Spring 1988): 8-10.

14. The reading of the date is by no means certain. A note on fol. 1a states: "Sir Denison Ross interpreted the difficult date of this $\mathrm{ms}$ as $654 \mathrm{~A} . \mathrm{H} .=1256 \mathrm{~A} . \mathrm{D}$. I took it to him to the Oriental School in London. W.W.F." Another way of reading this date would be $504 \mathrm{~A} . \mathrm{H}$. = 1110 A.H. Someone certainly read it this way for it is written in European figures at the bottom of the same folio. The year 504, however, could only be interpreted as the date of composition and not of transcription, unless the author did not die in $560 \mathrm{~A} . \mathrm{H}$. but earlier.
15. Meyerhof, "Études,": 20.

16. For the various practices connected with the critical apparatus in Arabic manuscripts see my "Technical practices and recommendations recorded by classical and post-classical Arabic scholars concerning the copying and correction of manuscripts," Les Manuscrits du Moyen Orient, éd. F. Déroche (Istanbul/Paris: 1988 forthcoming).

17. Professor Meyerhof's letter of 7.07 .1938 and a note by W. W. Francis on fol. 284b. 